號五第密四拾參第誌雜殺類人

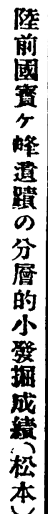

載でる る

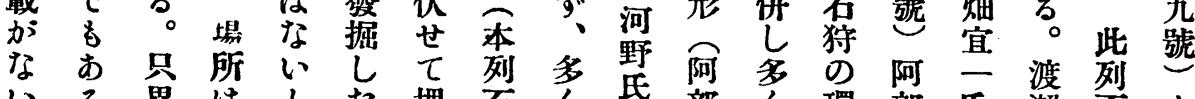
いる 異はとた埋石く部く環部氏 瀨石々

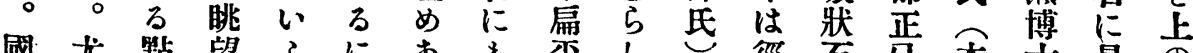
國尤點 望ふにある本しし徑石已本士最の 見もはよ。澡る

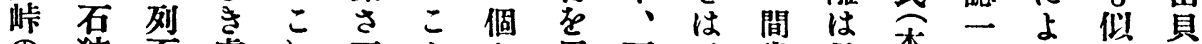
の狩石處 れ

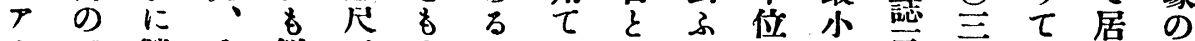

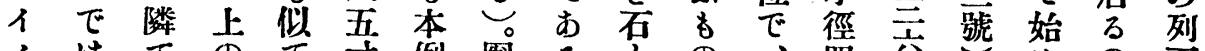

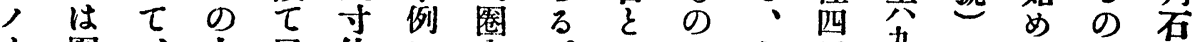

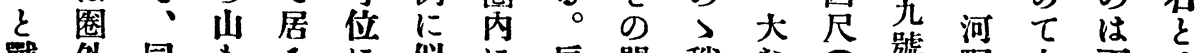
戰外同与るに似に扁間稍な 河㙱野本石は

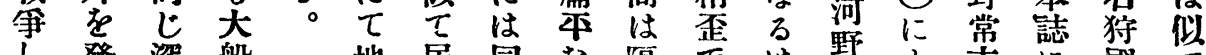

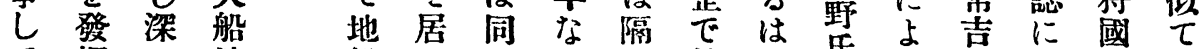
$\tau$ 掘 さ渡 死 調 に溜 骨查人查 きし 骨 望 埋た方 め 横 勝 江否了地 墓 かこで だ 記とお

博

士 陸

命 角

名成

石生

器 郡

時 前

代谷

遺 地

蹟 村

は 齊

多 藤

數 氏

の 邸

珍內

品な本

をる

産璸 彥

玉 せ 等

万峰

以故 郎

七 坪

有并

盤る大る

に。位を、圆間で追 守西石 万五若た形光公泣報地氺狀 がの芉の狀のるなせ理、石 理圈を が二は其踓 藏 内低多なな 正の狆三後て 物をくいらい圆、た六高

外この は れ が に 三 重

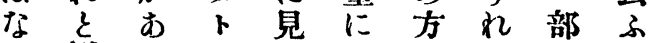
心似る1へなに驾口<smiles>[CH]</smiles>
小陸

發 前 掘國 成 䝷 績 ケ 峰

遺

蹟

の)

分

黁

的
たるつ笛圈は碑

本石、。元の和は 例特サ居け二ら信

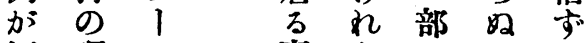
何環 事 どが がる

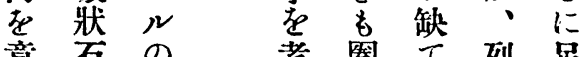
意石 9 考圈两列足 味 名名居石

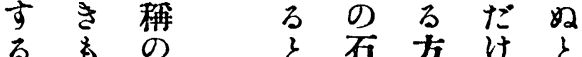
加其下 正の在でさ は二に面布入はね 姑にはは䈯口墓て く數種頭の主居 疑 5 今 の 狀すすはる 問れ 異 子 来 t2

ᄂつ形

七

置 がの
右及了い。

方圈々八本

にの 正 2 列

あ 一面。石

ろ部は 祭 る 如加屋 壇 墓 
白五十二月五年入正大

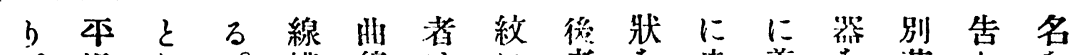

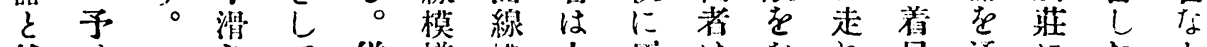

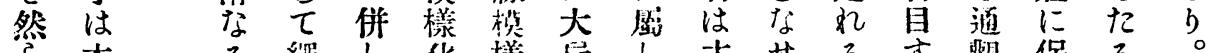

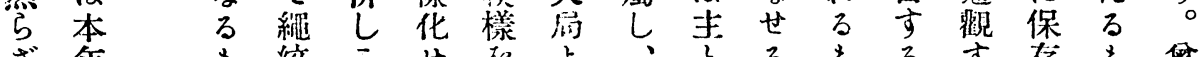

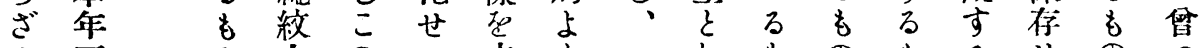

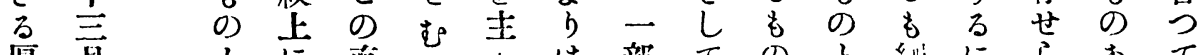

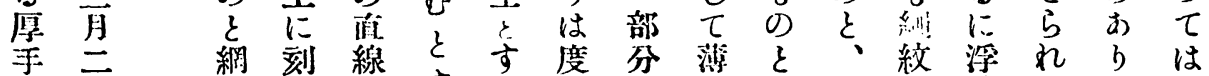

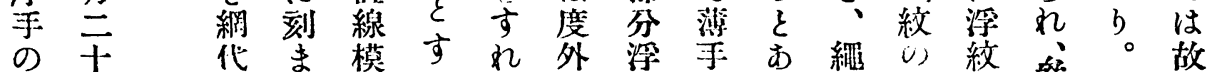

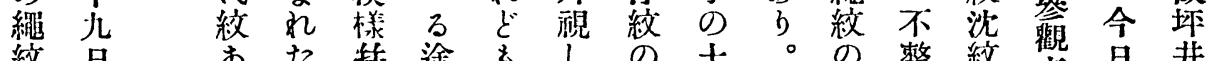

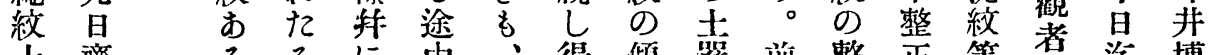

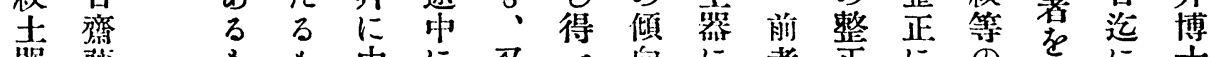

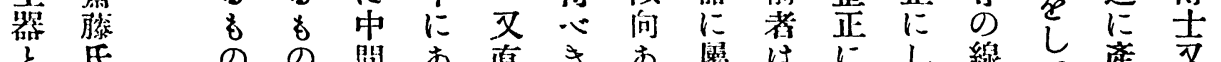
そ氏 の の

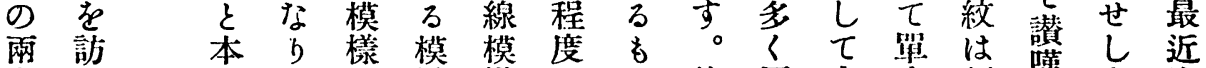

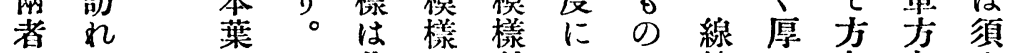
の $\tau$ 存 加 在: に旸 戕 狀 味 鷥 を晈 hit

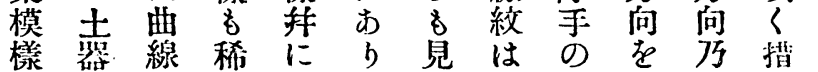
あ底模な曲。弓最士交至き遗氏 万面栐 ら 線線 る 火器代幾、此物等 もにとす模絞。多にし分單處はの のは同認栐は但數屬つ不にな褱累

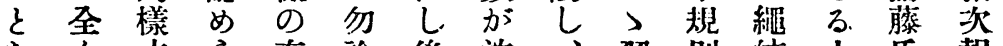

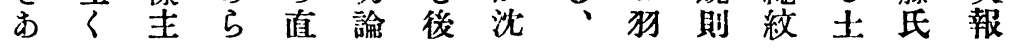

に何な 等

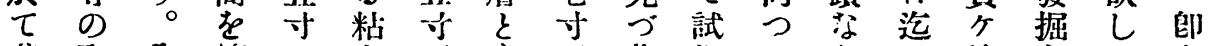

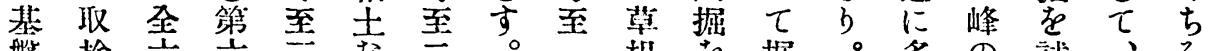

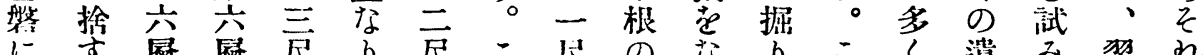

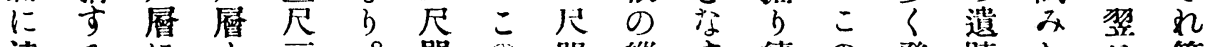

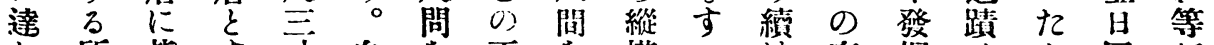

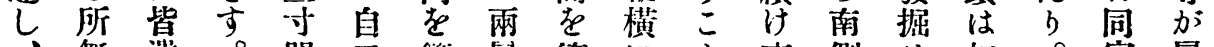

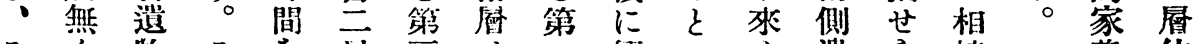

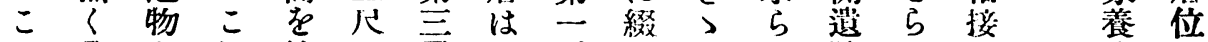

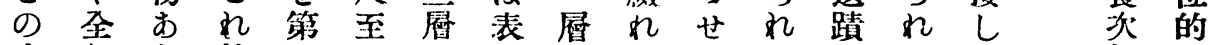

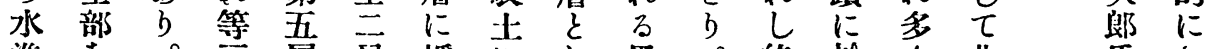

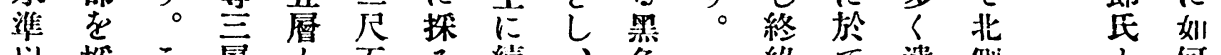

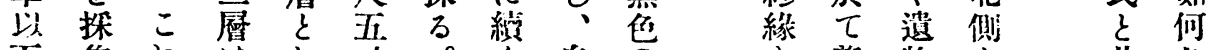

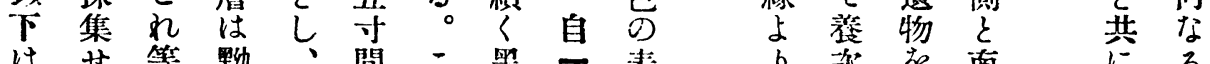

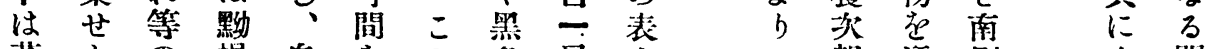

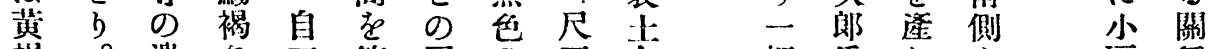

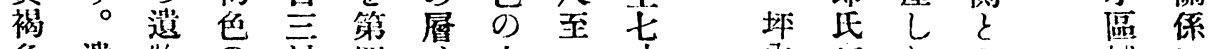

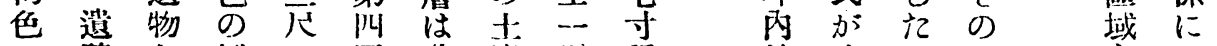

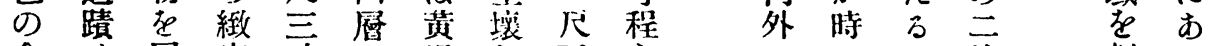

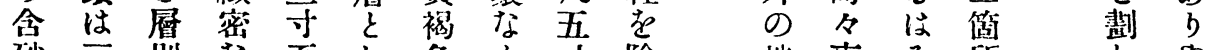
砂三别な 至し 色り 品除地東々所

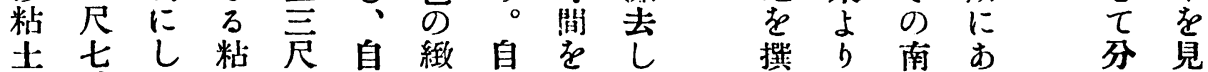

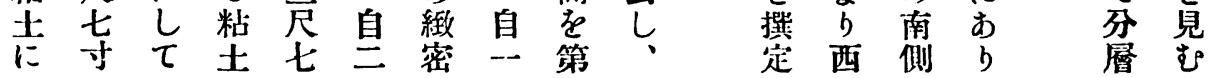


號五第然四拾參第誌雜學類人

陸

前

貫



些

造

漹

分

的

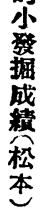

へ方設横て す 马線な線知はす必に

加向繩て に粒こ甚向正繩る線繩表:

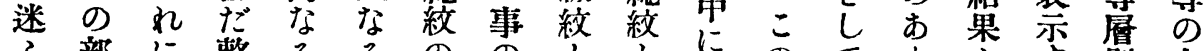

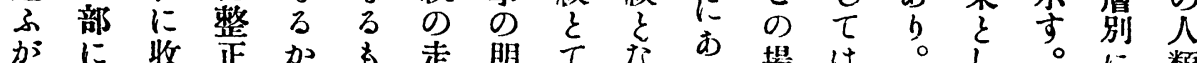
が收正加を走明てなる。埸は。類 如入むな邪の向なるし る 合線例

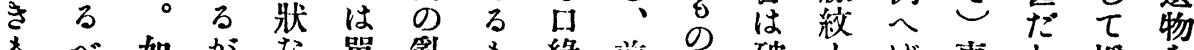

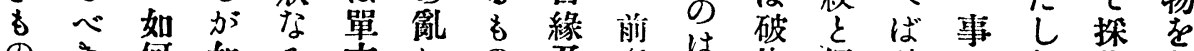
のき何如了方れの方渚は片繩破之き集含

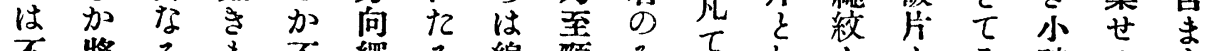

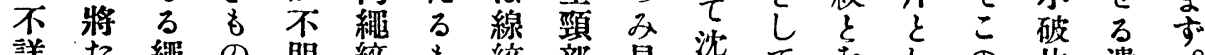

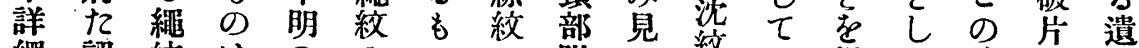

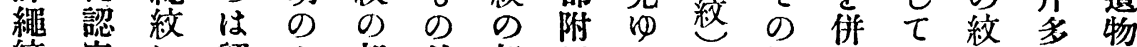
叔定に認を部並部近ると見有は樣导の

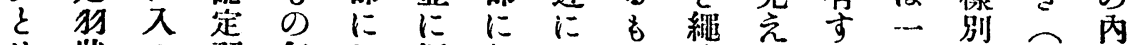

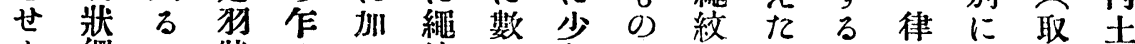

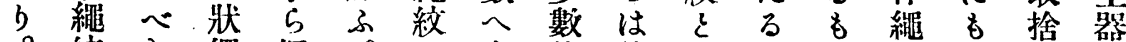
。紋き繩繩。のすす條線の所の紋頗無破

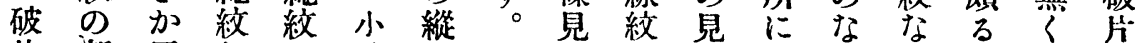
片部又な の破に小無ゆ從引苦集を

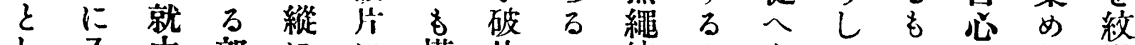

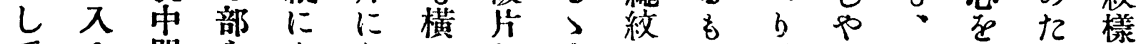

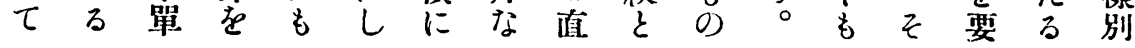

の 数 除

表 數 はき

表学上 社

二
第

展

第

瘄

第

扂

第

西

居

蒿

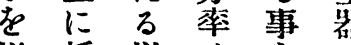

以括以は存以

七弧外厤な厤

示なの别さす

すき破にず

整詯 ᄂ

總 全

以 數 不

$\tau$ 娄 明

示以の

ᄂ宣憵

百字及

分底

率斿面

はb $b$

下。み

に破の

第

公

層
括 片 破

弧 0 ) 片

內 實 を

\section{數 僻}

個

個

$\tau$

\section{है}

ᄂ

\section{$=0$}

急

大 $\tau$ 口何 無 個筷称

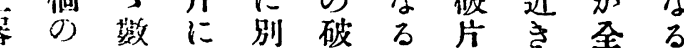
七はしつ片心部く 器肩て。艺しし分不の 底含點底念明は

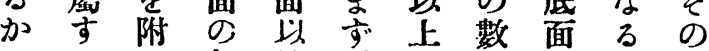
否了し部外。に はに置 か事てにの底は實近の無 疑 の示紋面底際きは紋 の明す重樣は面の部全の 存な事複に别の無分不部 寸 3 子 る。せ七既無樣士破と置

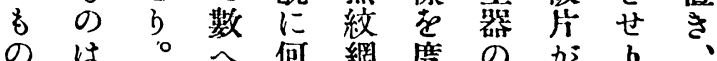
は は 數令處代荈數多多。紋

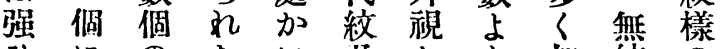
ひにのたに及しら加䔉の

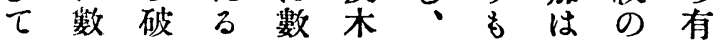
一へ片がへ葉 又著る部無 個、に如 5 紋底し老に艾 に一しきれの面く以は如 
日五十二月五年公正大

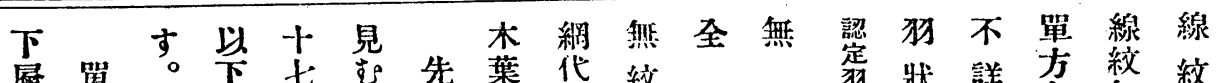

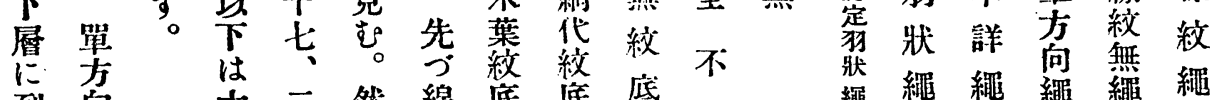
到 向 3 繩 は二然 線 底 䇙 底 程 晈 よは

第

な署

3 管

值 下

蛙

示甚

。无

第 な

層做

は老

㥯 示

少

小 且

干芆紋

五: 時繩

值十は紋

示八等線

しな順縗

第 一 の 繩

系 儘 紋

層 列 $に \cdot$

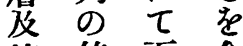

第 值 百

腐得率併

はへ か

小し九線

な第十督

傎第十。

$$
\begin{array}{lll}
0 & 0 & 1
\end{array}
$$$$
1,
$$$$
\text { 的 }
$$$$
\text { 走層公塞 }
$$

$\begin{array}{cccc}6 & 6 & 4 & 4 \\ (27) & (27) & (18) & (18)\end{array}$

2

列 第 の 四

值層牀

なれ 傾め

を 順 繩

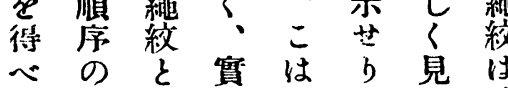

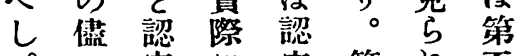

。に定に定第机五

二荡於旸二、唇

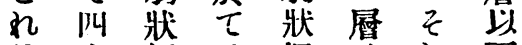

等十繩は繩はれ下

の涪政多政第上に

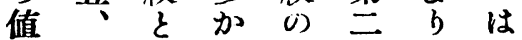

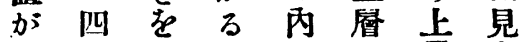

示十合心江奮ら

寸、侀し潜与好

意二市。み少至す，

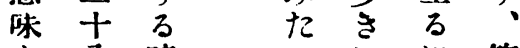

当公時方にに第

亦、は

說 九 自

明な第

の 万一

必一層

要 系 至

非從品

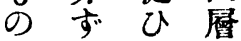

多やてに

增 於

加 觀 加 $\tau$

雼あの初

然列十值三は層 零 值

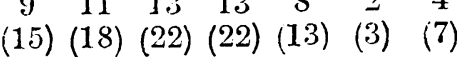

$\begin{array}{ccccccc}7 & 5 & 6 & 10 & 4 & 0 & 7 \\ (18) & (13) & (15) & (26) & (10) & & (18)\end{array}$

$\begin{array}{lllllll}16 & 1 & 6 & 1 & 39 & 2 & 11\end{array}$

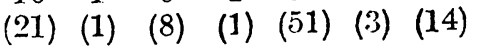

2:3 $00 \begin{array}{lllll}0 & 0 & 73 & 3 & 30\end{array}$

(57) (2) (23)

$\begin{array}{lll}35 & 1 & 9\end{array}$

(63) (2) (16)

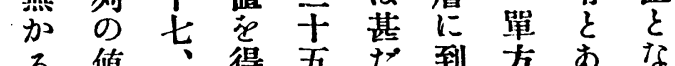

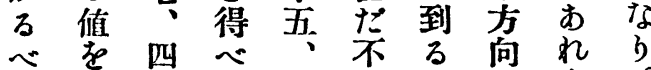
し 得士し三利程繩 ど。 心三。高少紋、第

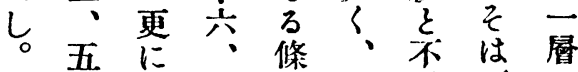
こ十こ五件旸詳不に れ四の土な狀鷥詳至

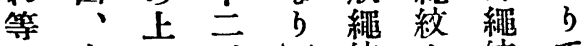

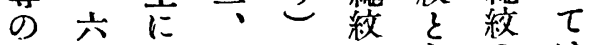
值十線五時は皇のは 加兵叔子は之合丙最 示: 繩七層に併にも 寸八紋、の反す潜少 意十共順卞るるる

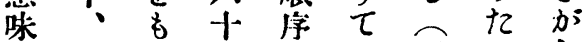
は罂合の單る如 說十俳应儘結方をし

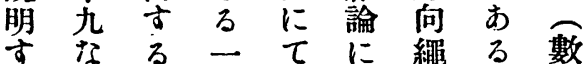
万る 時系十對紋べ字 迄二は列八し 分しに 
號五第悉四拾參第誌雜學類人

の樣 可分示面㔀む。

む蹟 揆見て せ繩

is

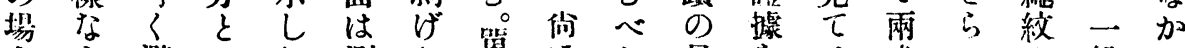

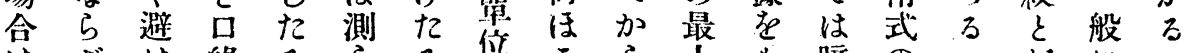

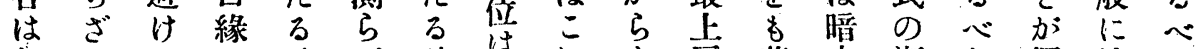

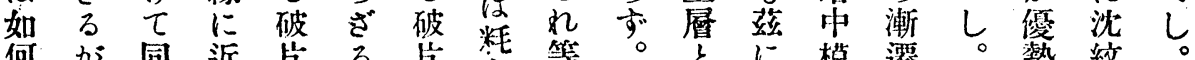

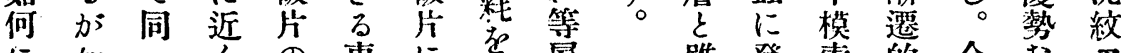

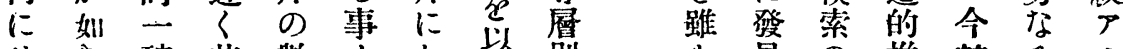

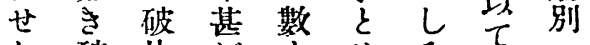

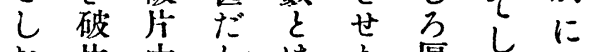

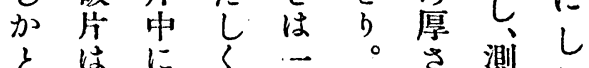

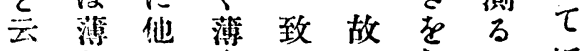
及きのく世に知に探 に部部なお゙测りは集 、分分れ。b得文世 キをるる士で゙ヤる 》採 測 部 器 る

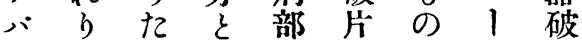

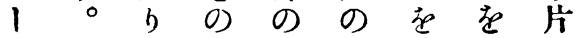
な丁口如肥数除㸝の

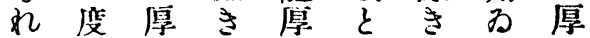
ば整薄はせ前、たさ さ數の 成る 表㕛り を る粍一る部に底。見

見の推丝る亿

未し觀移に式 邓 だ 得あ を閣 $る$ 式 旸江了題狗曲 状る雨示々 狀線 繩事式 せ 繩紋 紋と加る る 紋 橙 うは上を翼加期 全な卡の優の 盛和新峰染遗 期 b 古 b 遺な 跡 に。の。蹟るは 達但關而は式線 せし係し兩々紋

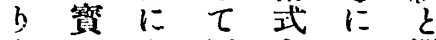
そ年 あ 别を二單 は峰る今筆大方 認遺の)に如向
第五士十九八七亲五四三三

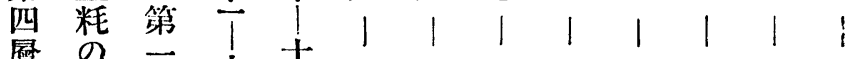

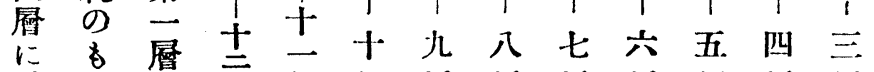

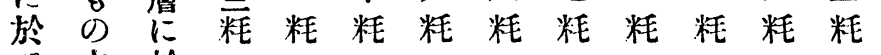

〔 己 は 齐

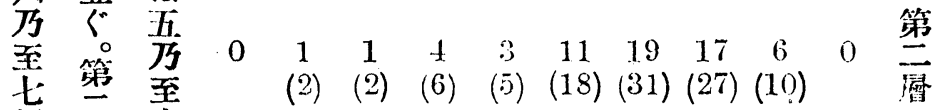

粍 臂 亲

$\begin{array}{llllllllllll}0 & \text { 第 }\end{array}$

第 0

0 第

最 層 D

悠曾最

勢 於優 (1)

穻.
於 勢

$\begin{array}{llll}l & \tau & i & 0\end{array}$

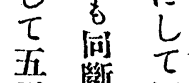

五 断

\begin{tabular}{lll} 
多 & 小 & 至 \\
六 & 。 & 至 \\
\hline
\end{tabular}
(5) (5) (18) (45) (27)

(3) (5)

(8) (21) (31) (28)

(5) (5) 蟹

10

\begin{tabular}{lllllllll}
4 & 9 & 10 & 24 & 18 & 10 & 0 & 0 & 算 \\
\hline 4
\end{tabular}

(5) (12) (13) (32) (24) (13)

0

(1)

(1)

8

(6)

1
$(2)$

(2) (2)

(2) (2)

(9) $(30)(30)(16)$

(7) (2)
二數置 場 韭直 测合 分 b 殆 茶 调

とし 起 の $\tau \zeta$ 示文 诂 稀 はのに 前 偏 起 表り り E 加L 同指際

し示は 万湴 所少 徐远 人異 b ई 筫 位 
日五十二月五年八正大

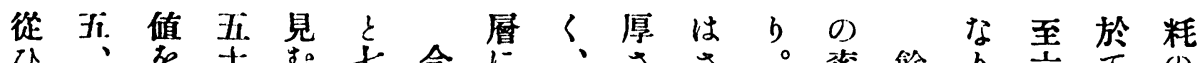

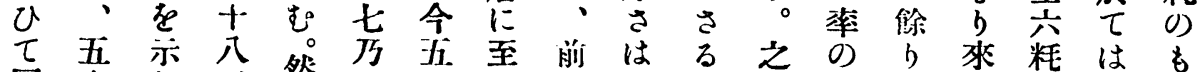

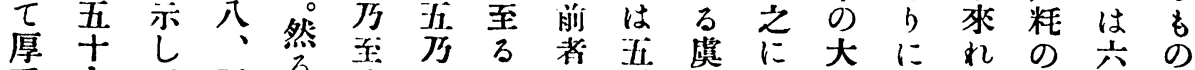

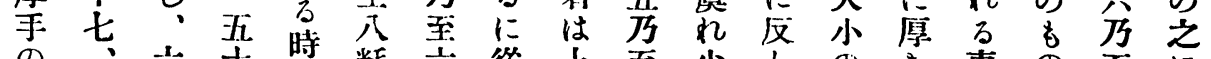

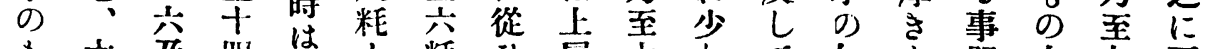

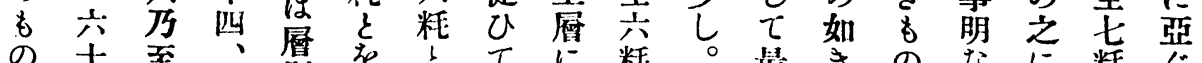

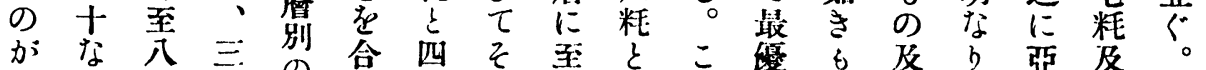

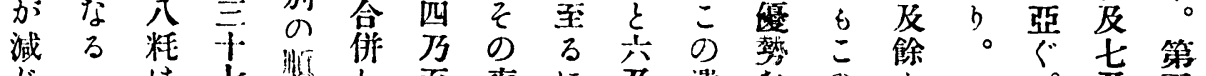

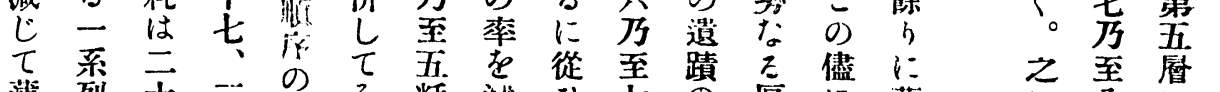

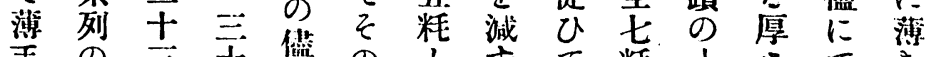

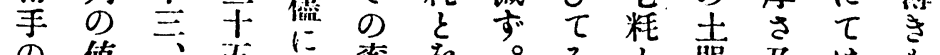

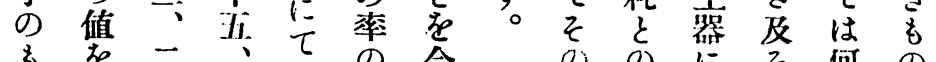

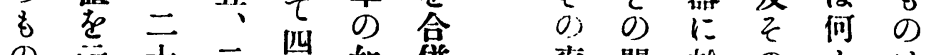

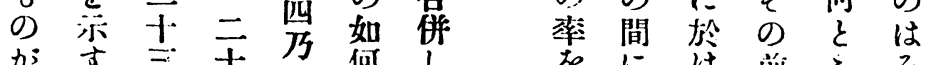

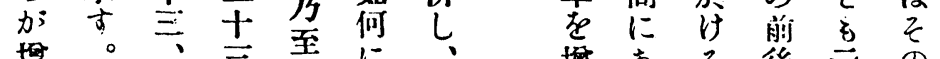
買。一主至に增

す 青 三 な 粕 增 爻 る し 傾に兄三は減分 向至、系尤乃圭 糜 3 四列 然に十の ○专粍

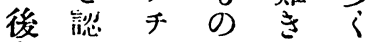
者め力にる に は得少於手元 上・゙のて
解のに的人い

にで脬性程か人

當あ諭啠性、種

然 3 せ

考察己開云假は

せ祭市題㕣り 或

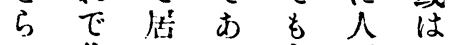

万先るる人程民

心方分程性族

き是、從 0$) \xi$ 性

は、等 未來體し

其

の 題 分 程 問市は

研を ひ の 题研國

究决科開で究民

の 定孟題は法性

方守的は学占

詓に諣常く、論し䚴芳

ではを其る る

あ、得加少。差

る 其なら忍脗支
3

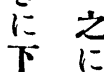

万依

O

人

種

性

の)

研

究

1

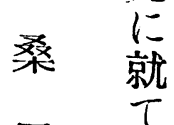

田

藏
に八に

俄粍於

万の $\tau$

है है है

上の同

層 最 斷

の 優な

8 勢 b

の に。

程 1，第

溥 $\tau$ 六

手 五 層 